\title{
Yellow sac spiders
}

\author{
Georg Röggla
}

Received: 6 October 2017 / Accepted: 12 October 2017 / Published online: 6 November 2017

(c) Springer-Verlag GmbH Austria 2017

\section{Dear editors,}

my team read Tanja Varl and co-workers well-balanced review on yellow sac spider bites in our southern neighboring country with great interest [1]. There has been quite some hysteria related to yellow sac spiders in the past years. We would therefore like to draw attention to a few issues: my team first saw a bite by a yellow sac spider in Lower Austria approximately 10 years ago [2]. Shortly before the BBC, which does not often report medical facts from Austria, reported that 190 people had attended the general hospital in Linz in Upper Austria within 2 weeks because of fear of a spider bite [3]. We would also like to add additional spider retreats to those mentioned by the authors: Mazda recalled 67,000 cars over fears that colonies of yellow sac spiders could set the fuel tanks on fire [4]. Other car producers faced similar problems. What looked like a well thought out April fool's joke turned out to be a major problem. The exaggerated fear of yellow sac spiders has entirely cooled down in the meanwhile.

Conflict of interest G. Röggla declares that he has no competing interests.

\section{References}

1. VarlT, GrencD, KostanjsekR, Brvar M. Yellowsac spider bites in Slovenia: case series and review. Wien Klin Wochenschr. 2017;129:630-3.

2. Fasan M, Rennhofer A, Moser B, Röggla G. Spider myths and a case of a bite by a yellow sac spider. J Am Board Fam Med. 2008;21:78.

3. BBC News. 2006. http://news.bbc.co.uk/2/hi/europe/ 5244840.stm. Accessed 5 Oct 2017.

4. MailOnline. 2011. http://www.dailymail.co.uk/news/ article-1362679/Mazda-recalls-1000s-cars-fears-Yellowsac-spiders-set-fuel-tanks-fire.html\#ixzz4ucptjn6U. Accessed 5 Oct 2017. 